\title{
Membangun Manajemen Kearifan Lokal (Studi pada Kearifan Lokal Orang Banjar)
}

\author{
Titien Agustina \\ Dosen Sekolah Tinggi Ilmu Manajemen Indonesia (STIMI) Banjarmasin
}

\begin{abstract}
The Banjar people are the majority population of the Province of South Kalimantan, having diverse local wisdom. The uniqueness is in language, proverbs in oral communication, handycrafts on Banjar clothing or houses, knick-knacks and selected colors on Banjar traditional clothes, culinary possessions, as well as economic activities, community social activities, all characterized by uniqueness and diversity that is rich in philosophy. This research was conducted based on a review of the literature review with a qualitative approach. The aim is to identify and analyze the results of the local wisdom of the Banjar people in managing the uniqueness of the customs of culture, language, and the results of civilization that emerge as thoughts, inventions, feelings and intentions contained in the results of interacting with the external environment that give birth to values different from other ethnic groups
\end{abstract}

Keywords : manage, Banjar cultural customs, local wisdom, Banjar People, South Kalimantan

Abstrak

Orang Banjar adalah penduduk mayoritas Provinsi Kalimantan Selatan memiliki kearifan lokal yang beragam. Keunikan ada pada bahasa, peribahasa dalam komunikasi oral, handycraft pada pakaian maupun rumah Banjar, pernak-pernik dan warna yang dipilih pada pakaian adat Banjar, kuliner yang dimilikinya, serta kegiatan ekonomi, kegiatan sosial kemasyarakatan, semua mencirikan keunikan dan keragaman yang kaya filosofi. Penelitian ini dilakukan berdasarkan pada telaah kajian literatur dengan pendekatan kualitatif. Dilakukan dengan tujuan untuk mengidentifikasi dan menganalisis hasil-hasil kearifan lokal Orang Banjar dalam mengelola keunikan adat budaya, bahasa, maupun hasil peradaban yang muncul sebagai buah pemikiran, cipta, rasa dan karsa yang terkandung di dalam hasil berinteraksi dengan lingkungan eksternal yang melahirkan nilai dan norma yang berbeda dengan suku bangsa lainnya.

Kata Kunci : tata kelola, adat budaya Banjar, kearifan lokal, Orang Banjar, Kalimantan Selatan

\section{PENDAHULUAN}

\section{Latar Belakang}

Indonesia sebagai negara plural, memiliki keaneka-ragaman budaya sebagai hasil dari karya, rasa dan cipta masyarakatnya memerlukan perawatan yang baik. Keaneka-ragaman budaya tersebut adalah suatu kearifan lokal (local wisdom). Kearifan lokal mengandung banyak makna yang berisi nilai-nilai luhur dan norma-norma yang disepakati sebagai bagian dari kehidupan masyarakat tersebut. Kearifan lokal yang sudah ada dan tumbuh terpelihara dalam masyarakat Indonesia merupakan kekayaan Nusantara yang menjadi nilai plus untuk dilestarikan karena menarik untuk wisatawan sebagai sesuatu yang unik dari suatu kelompok masyarakat dunia. Pada saatnya bisa menjadi objek pariwisata yang bernilai ekonomi bagi masyarakat itu dan juga pemerintah. Bahkan pun bisa menjadi bahan kajian ilmiah bagi para ahli di banyak bidang keilmuan.

Kalimantan Selatan sebagai bagian dari Indonesia, juga memiliki beragam suku bangsa, agama, kepercayaan, budaya dan adat istiadat yang bisa saja berbeda satu tempat dengan lainnya, sehingga pasti ada banyak beragam kearifan lokal yang dimiliki. Apalagi dengan mayoritas penduduknya bersuku Banjar, namun juga memiliki etnik yang berbeda pada tiap tempat. Sehingga dikenal pula istilah Banjar Kuala dan Banjar Hulu atau Pahuluan. Masyarakat atau Suku Banjar Kuala umumnya berdiam di daerah dataran rendah dan pesisir sungai. Masyarakat atau Suku Banjar Hulu atau Pahuluan, umumnya berdiam di daerah dataran tinggi, pegunungan-pegunungan yang tersebar di sekitar Pegunungan Meratus dan lainnya.

Provinsi Kalimantan Selatan memiliki 13 kabupaten/kota dengan kekhasan masing-masing yang melahirkan kearifan lokal setempat. Ini merupakan kekayaan Bangsa yang sebenarnya harus dilestarikan di tengah gencarnya arus globalisasi dan modernisasi sekarang ini. Tetapi sayang banyak kearifan lokal Orang Banjar yang belum tergali, tertata, dan terpublikasikan dalam bentuk terbitan yang bisa diwariskan dari generasi ke generasi. Sebagai buah dari pola pikir, sikap dan perilaku yang mencerminkan sebuah nilai dan norma yang dianut. Sampai saat ini masih banyak berceceran hasil perilaku dan pemikiran tersebut dan belum terdokumentasi dengan baik, apalagi 
sampai diterbitkan menjadi sebuah karya monumental (buku tercetak). Padahal semua kearifan lokal yang ada bisa menjadi warisan budaya bagi generasi mendatang. Sangat diperlukan adanya pencatatan dan pendokumentasian serta peran pengawasan yang dijalankan melalui manajemen yang baik. Sehingga kekuatiran terjadinya degradasi karena masuknya budaya baru tidak akan terjadi. Generasi mendatang tetap mengenal dan mengetahui sejarah asal muasal suatu budaya, adat, kebiasaan, falsafah, maupun makna dibalik suatu sikap atau perilaku tertentu leluhurnya. Tidak akan terjadi kekuatiran yang berlebihan bila adat budaya sudah terekam dengan baik dan apik.

Demikian pula bila semua kearifan lokal Orang Banjar sudah dikelola dengan baik, tercatat dengan tata kelola atau manajemen yang teratur, dalam bentuk bukti hitam atas putih (penerbitan), maka akan dengan mudah ditelusuri asal mula suatu tindakan, kebiasaan, tergali, tertata, dan terpublikasikan sebagai warisan ke generasi berikutnya. Hasil budaya akan menjadi kekhasan atau keunikan sendiri yang akan mengawal masyarakat dalam berinteraksi dengan arus globalisasi dan budaya modern. Kearifan lokal juga bisa menjadi filter dan rambu-rambu akan suatu perilaku dan budaya baru yang masuk. Selain itu juga bisa menjadi sinyal tentang sesuatu nilai, norma, dan makna yang tidak sejalan dengan nilai dan norma yang ada akan mudah terdeteksi.

Oleh karena itu kearifan lokal atau local wisdom merupakan bagian dari budaya suatu masyarakat yang tidak dapat dipisahkan dari "Bahasa" masyarakat itu sendiri. Kearifan lokal biasanya diwariskan secara turun temurun dari satu generasi ke generasi melalui cerita dari mulut ke mulut. Kearifan lokal ada di dalam cerita rakyat, peribahasa, lagu, dan permainan rakyat, kepercayaan, maupun dalam budaya yang hidup bersama masyarakat yang melahirkan suatu kebiasaan. Sehingga kearifan lokal bisa sebagai suatu pengetahuan yang ditemukan oleh masyarakat lokal tertentu melalui kumpukan pengalaman dalam mencoba dan diintegrasikan dengan pemahaman terhadap budaya dan keadaan alam lingkungan suatu tempat.

Pada awalnya kearifan lokal berkembangan dan lahir dari mulut ke mulut. Kemudian dengan perkembangan budaya masyarakatnya, kearifan lokal bisa menjadi kuat keberadaannya sehingga mampu eksis dalam beberapa generasi. Pada era modern sekarang ini, dimana masyarakat sudah banyak terbantu dengan alat komunikasi dan kecanggihan teknologi informasi lainnya, maka banyak kearifan lokal menjadi kurang diperhatikan, bahkan cenderung diabaikan, hanya dibiarkan sebagai budaya oral tanpa merasa penting dan perlu untuk diangkat dalam sebuah buku, maka pada akhirnya ada kemungkinan menjadi terkikis dan hilang dari peredarannya ditengah masuknya budaya baru.

Sifat hukum adat pada umumnya tidak tertulis, hanya sebagai kebiasaan berperilaku masyarakat lokal. Banyak sekali kearifan lokal masyarakat dan pengelolaannya yang tidak diketahui banyak orang apa makna dan tujuannya, terutama dalam konteks ilmiah (Zulkarnain, et al. 2008). Oleh karena itu kearifan lokal suatu kelompok masyarakat sangat penting sekali untuk digali dan diangkat menjadi karya monumental dan didokumentasikan dengan baik melalui lembaga penerbitan. Ini merujuk pada kegiatan administrasi dan manajemen yang baik sehingga keilmiahannya bisa diuji. Selain itu juga bisa membantu generasi yang akan datang untuk menelusuri adat budaya nenek moyangnya. Serta dengan terpeliharanya kearifan lokal suatu kelompok masyarakat, maka riwayat generasi masyarakat itu tidak akan terputus begitu saja oleh degradasi nilai-nilai dan norma yang memudar karena perubahan dan tantangan kehidupan yang semakin kompleks. Melalui tata kelola penulisan dan penerbitan akan hasil-hasil kearifan lokal masyarakat yang dituangkan secara rapi dan professional dalam konteks ilmiah, maka akan menjadikan kearifan lokal masyarakat itu tetap terjaga dan lestari dari generasi ke generasi.

Selain itu, kearifan lokal juga akan bisa menjadi modal pembangunan yang mendongkrak ekonomi rakyat/masyarakat. Karena melalui kearifan lokal yang terpelihara dengan baik dan apik, maka keunikan dan khas milik masyarakat itu bisa "dijual" sebagai modal pariwisata. Karena keunikan suatu masyarakat dengan segala buah pikir, sikap dan perilaku hidupnya akan bisa menjadi daya tarik tersendiri dalam pembangunan pariwisata.

\section{Rumusan Masalah}

Kalimantan Selatan mayoritas penduduknya adalah Suku Banjar (74,34\%) memiliki kebiasaankebiasaan sebagai hasil dari pola pikir, sikap, dan perilaku yang menjadi tata nilai dan norma sehingga melahirkan kearifan lokal Masyarakat/Orang Banjar, pasti memiliki perbedaan dengan kelompok masyarakat lainya. Penelitian ini dilakukan dengan rumusan masalah berikut:

1. Apakah kearifan lokal Orang Banjar sudah dicatat, didokumentasikan, diterbitkan dan dipublikasikan dengan baik sehingga nilainilai dan budaya yang dihasilkan sebagai warisan dari peradaban masyarakat Banjar sudah berjalan melalui manajemen yang baik?

2. Apakah peran cerdas cendekia Orang Banjar sudah melakukan kegiatan pengadministrasian dan manajemen yang baik dalam konteks ilmiah di dalam penulisan, penerbitan, dan publikasi akan hasil-hasil kearifan lokal Masyarakat Banjar melalui media penerbitan? 


\section{Tujuan Penelitian}

Adapun tujuan dari penelitian ini adalah:

1. Mengindentifikasi kearifan lokal Orang Banjar apakah sudah dicatat, didokumentasikan, diterbitkan dan dipublikasikan dengan baik sehingga nilainilai dan budaya yang dihasilkan sebagai warisan dari peradaban masyarakat Banjar sudah berjalan melalui proses manajemen yang baik.

2. Mengidentifikasi dan menganalisis peran cerdas cendekia Orang Banjar apakah sudah melakukan kegiatan pengadministrasian dan manajemen yang baik dalam konteks ilmiah di dalam penulisan, penerbitan, dan publikasi akan hasil-hasil kearifan lokal Masyarakat Banjar melalui media penerbitan.

\section{METODE PENELITIAN}

Penelitian ini menggunakan metode studi pustaka atau literatur, dimana maksudnya peneliti giat mempelajari literatur yang diperlukan dalam penelitian (Nazir, 2014: 79). Penelitian ini menggunakan pendekatan kualitatif sebagai penelitian eksploratif yang tidak terstruktur. Studi literatur selain dari menggunakan sumber data sekunder yang akan mendukung penelitian, juga diperlukan untuk mengetahui sejauh mana penelitian yang berkaitan dengan ilmu pengetahuan telah berevolusi, sampai sejauh mana kesimpulan dan degenerasi telah dibuat, sehingga situasi yang diperlukan dapat diperoleh (Nazir, 2014: 79).

Sumber data penelitian ini menggunakan data sekunder. Data sekunder adalah data yang secara tidak langsung memberikan data kepada peneliti (Sugiyono, 2014: 163) atau data yang telah dikumpulkan oleh lembaga pengumpulan data dan dipublikasikan ke pengguna data publik. Data sekunder dalam penelitian ini diperoleh dari referensi melalui studi literatur, seperti buku referensi, jurnal, artikel, dan sumber lain yang relevan dengan penelitian.

Penelitian ini selain menggunakan jenis penelitian kualitatif dengan metode studi pustaka juga pengamatan langsung ke objek, sehingga pengumpulan data dalam penelitian ini selain dari buku referensi juga menggunakan sumber-sumber berikut:

1. Buku teks adalah buku-buku ilmiah yang ditulis dengan rapi yang diterbitkan dengan intercal yang tidak terbatas;

2. Jurnal, yaitu majalah ilmiah yang berisi karya ilmiah atau hasil seminar;

3. Secara berkala, yaitu majalah ilmiah yang diterbitkan secara berkala oleh lembaga pemerintah atau swasta yang berisi hasil-hasil penelitian.

4. Pengamatan langsung pada objek penelitian di lapangan.
Dalam studi ini, tinjauan literatur menggunakan literatur lokal yang sangat banyak tersebar. Data dalam laporan ini dibandingkan, diringkas, dan ditafsirkan untuk mendapatkan wawasan berharga ke dalam praktik tentang pengadministrasian dan tata kelola atau manajemen kearifan lokal yang dikembangkan dalam masyarakat Banjar selama ini. Rekomendasi diberikan juga untuk menyempurnakan dan meningkatkan manajemen kearifan lokal ditengah derasnya gempuran arus globalisasi dan perubahan jaman.

Untuk memudahkan penelitian ini maka perlu menetapkan definisi operasional sebagai berikut:

1. Kearifan lokal adalah beberapa prinsif dan cara tertentu yang dianut, dipahami, dan diaplikasikan oleh masyarakat lokal dalam berintegrasi dan berinterelasi dengan lingkungannya dan dipublikasikan dalam bentuk system nilai dan norma (Zulkarnain $e t$. al, 2008).

2. Manajemen kearifan lokal adalah proses yang dilakukan secara bersama oleh suatu kelompok masyarakat guna meraih tujuan bersama melalui identifikasi, pengelolaan, penataan, pendokumentasian dan publikasi yang mudah diakses melalui konteks ilmiah.

3. Orang Banjar adalah orang dari suku Banjar atau bumiputera yang mayoritas mendiami Provinsi Kalimantan Selatan.

4. Penerbitan adalah suatu usaha atau kegiatan yang berkaitan dengan proses editorial, produksi, dan pemasaran idea/gagasan dalam konteks ilmiah yang didistribusikan kepada pembaca melalui cetakan.

Publikasi adalah suatu cara untuk mengenalkan sesuatu, dalam hal ini buah pikiran, sikap dan perilaku beserta filosofinya sehingga adat istiadat tersebut dapat diketahui dan dipahami makna dibalik perilaku atau adat kebiasaan itu.

\section{HASIL PENELITIAN DAN PEMBAHASAN}

\section{Keadaan Geografis}

Secara geografis Kalimantan Selatan berada di bagian tenggara Pulau Kalimantan yang memiliki kawasan dataran rendah di bagian barat dan pantai timur, serta dataran tinggi yang dibentuk oleh Pegunungan Meratus di tengah. Kalimantan Selatan terdiri atas dua ciri geografi utama, yaitu dataran rendah dan dataran tinggi sehingga melahirkan kondisi alam yang berbeda. Pada Kawasan dataran rendah kebanyakan berupa lahan gambut hingga rawa-rawa sehingga kaya dengan sumber keanekaragaman hayati satwa air tawar. Pada kawasan dataran tinggi sebagian masih merupakan hutan tropis alami dan dilindungi oleh pemerintah yang berbentuk hutan tetap, hutan produksi, hutan 
lindung, hutan konvensi. Kemudian juga perkebunan, bahan galian sumber daya alam seperti batu bara, minyak, pasir kwarsa, biji besi, dll. Kondisi geografis yang berbeda ini melahirkan pula adat dan kebiasaan atau budaya masyarakat Orang Banjar yang berbeda-beda pula pada beberapa tempat. Baik menyangkut Bahasa, kebiasaan, cara memaknai sesuatu, dll. Ini karena pengaruh lingkungan alam, interaksi sosial dan perkembangan intelektual serta keyakinan yang lalu membentuk pola pikir, sikap dan perilaku yang berbeda dalam nilai dan norma yang dimiliki masyarakat itu.

\section{Jumlah Penduduk dan Penyebaran}

Penduduk Kalimantan Selatan berjumlah 3.613.992 jiwa dengan menyebar di 13 Kabupaten/Kota se Kalimantan Selatan. Mayoritas suku Banjar atau Orang Banjar asli berjumlah 2.686.627 jiwa $(74,34 \%)$ yang merupakan etnis mayoritas yang terdiri dari 3 (tiga) kelompok, yaitu Banjar Kuala (mendiami kawasan Banjar Bakula atau hilir Sungai Barito dan anak-anak sungainya). Kemudian Banjar Pahuluan (mendiami kawasan hulu Banua Anam atau aliran-aliran sungai yang berhulu di Pegunungan Meratus; dan Banjar Batang Banyu (mendiami Kawasan hilir Banua Anam pada aliran Sungai Nagara) (Wikipedia). Selebihnya 927.363 jiwa adalah suku diluar Suku Banjar yang terlihat dalam Tabel 1 berikut:

Tabel 1 Penduduk Kalimantan Selatan berdasarkan Suku Bangsa

\begin{tabular}{clcc}
\hline No & $\begin{array}{c}\text { Nama } \\
\text { Suku }\end{array}$ & $\begin{array}{c}\text { Jumlah } \\
\text { penduduk }\end{array}$ & Persentase \\
\hline 1 & Banjar & 2.686 .627 & 74,34 \\
\hline 2 & Jawa & 524.276 & 14,51 \\
\hline 3 & Bugis & 101.727 & 2,81 \\
\hline 4 & Dayak & 80.708 & 2,23 \\
\hline 5 & Madura & 39.841 & 1,10 \\
\hline 6 & Sunda & 24.592 & 0,68 \\
\hline 7 & Tionghoa & 13.000 & 0,36 \\
\hline 8 & Batak & 12.408 & 0,34 \\
\hline 9 & Bali & 11.966 & 0,33 \\
\hline 10 & Suku- & 65.845 & 1,82 \\
& suku & & \\
\hline & lainnya & & 100 \\
\hline
\end{tabular}

\section{Karakteristik Sosial}

Orang Banjar yang mendiami Provinsi Kalimantan Selatan memiliki karakteristik sosial budaya dan ekonomi yang khas dari kearifan masyarakat dan alamnya yang bisa dikelompokkan dalam beberapa unsur, yaitu:
1. Sistem kekerabatan
2. Bahasa
3. Suku
4. Agama
5. Mata pencaharian

6. Seni dan budaya

7. Tekstil

8. Kuliner

Untuk mata pencaharian atau ekonomi Orang Banjar yang mendiami Kalimantan Selatan dapat dikelompokkan atas:
1. Petani
2. Pedagang
3. Nelayan
4. PNS
5. Swasta
6. Buruh
7. Lain-lain

Kegiatan Sosial Kemasyarakatan Orang Banjar Dalam kegiatan sosial kemasyarakatan Orang Banjar juga memiliki kepedulian sosial dan suka membangun relasi dalam rangka mengembangkan jiwa sosial kemasyarakatannya. Karena pada dasarnya Orang Banjar beragama Islam sehingga dalam banyak kegiatan sosialnya tidak lepas dari hubungan dan pengaruh agama Islam yang dianutnya sehingga Orang Banjar atau Kalimantan Selatan sering disebut masyarakat religius. Karena segala sesuatu yang dilakukan selalu tidak lepas dari agama Islam di dalam memberi pemaknaan. Walaupun ada adat budaya yang tidak berasal dari ajaran Islam, namun setelah Islam menjadi agama Orang Banjar, maka segala sikap dan perilaku budaya itu diberikan pemaknaan yang sesuai dengan ajaran Islam.

Tabel 2 berikut adalah hasil identifikasi tentang kegiatan sosial kemasyarakatan Orang Banjar dalam berbagai aspek kehidupan, dari yang terkait dengan keperluan pribadi/individu maupun keperluan bersama dalam kehidupan sosialnya.

Tabel 2. Kegiatan Sosial Kemasyarakatan Orang Banjar

\begin{tabular}{|c|c|c|c|}
\hline No & Nama Kegiatan & Peruntukan & $\begin{array}{l}\text { Makna sosialnya } \\
\end{array}$ \\
\hline 1 & Ba'tasmiah & $\begin{array}{l}\text { Memberi nama } \\
\text { kepada anak yang } \\
\text { baru dilahirkan. }\end{array}$ & $\begin{array}{l}\text { Mengundang/mengumpulkan } \\
\text { banyak orang/kerabat/dll. }\end{array}$ \\
\hline 2 & Ba'aqiqah/Aqiqah & $\begin{array}{l}\text { Melaksanakan } \\
\text { aqiqah sebagai } \\
\text { bagian dari ajaran } \\
\text { Islam. }\end{array}$ & $\begin{array}{l}\text { Mengundang/mengumpulkan } \\
\text { banyak orang/kerabat/dll. }\end{array}$ \\
\hline 3 & Ba'mandi-mandi & 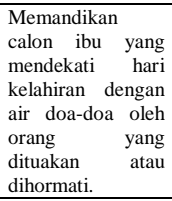 & $\begin{array}{l}\text { Mengundang/mengumpulkan } \\
\text { banyak orang/kerabat/dll. }\end{array}$ \\
\hline 4 & Ba'tapung tawar & $\begin{array}{lr}\text { Kegiatan } & \text { yang } \\
\text { biasanya } & \\
\text { dilaksanakan } \\
\text { seiring } & \text { dengan } \\
\text { acara } & \text { mandi- } \\
\text { mandi } & \text { yang } \\
\text { dilaksanakan } & \text { oleh } \\
\text { seorang } & \text { tokoh } \\
\text { atau } & \text { yang } \\
\text { dituakan } & \text { karena } \\
\text { ilmu dan usia, dll. } \\
\text { Umumnya } & \text { dalam } \\
\text { hitungan } & \text { ganjil. } \\
\text { Tapung } & \text { tawar } \\
\text { dibuat } & \text { dari } \\
\text { minyak } & \text { likat } \\
\text { baboreh } & \text { yang } \\
\text { dicelup } & \text { dengan } \\
\text { daun pisang yang }\end{array}$ & $\begin{array}{l}\text { Biasanya diikuti dengan } \\
\text { menyediakan "piduduk" } \\
\text { berupa segantang (5 liter) } \\
\text { beras, gula merah, sebiji } \\
\text { kelapa, ayam (betina hitam), } \\
\text { pisau, benang, jarum, lilin, } \\
\text { sisir, sesuap sirih menginang, } \\
\text { rokok daun dan rerempah } \\
\text { bumbu dapur. Piduduk ini } \\
\text { diberikan kepada bidan } \\
\text { kampung yang memimpin } \\
\text { upacara. Sedang kepada } \\
\text { hadirin diberikan teh manis } \\
\text { atau kopi, bubur sum sum, } \\
\text { wajik atau ketan berinti kelapa } \\
\text { muda, cucur, wadai gincil, } \\
\text { bubur habang dan bubur putih. }\end{array}$ \\
\hline
\end{tabular}




\begin{tabular}{|c|c|c|c|c|c|c|c|}
\hline \multirow[t]{4}{*}{ No } & Nama Kegiatan & \multirow{3}{*}{\begin{tabular}{l}
\multicolumn{2}{l}{ Peruntukan } \\
dihijir terlebih \\
dahulu kemudian \\
dicelupkan r ke \\
minyak r likat \\
baboreh ralu \\
dipercikan pada \\
kepala, pundak, \\
telapak tangan dan
\end{tabular}} & \multirow[t]{4}{*}{ Makna sosialnya } & \multirow[t]{2}{*}{ No } & \multirow[t]{2}{*}{ Nama Kegiatan } & \multirow[b]{2}{*}{$\begin{array}{l}\text { Peruntukan } \\
\text { rumah ke rumah } \\
\text { setiap anggota } \\
\text { atau dikhususkan } \\
\text { di Mushalla, dll }\end{array}$} & \multirow[t]{2}{*}{ Makna sosialnya } \\
\hline & & & & & & & \\
\hline & & & & 15 & Pengajian & $\begin{array}{lr}\text { Membaca } & \text { kitab } \\
\text { suci Al Qur'an, } \\
\text { syair puji-pujian } \\
\text { kepada } \quad \text { Nabi }\end{array}$ & $\begin{array}{l}\text { Diikuti setiap orang yang } \\
\text { menjadi peserta atau pun yang } \\
\text { berminat. Umumnya sudah } \\
\text { ada anggota tetap pengajian. }\end{array}$ \\
\hline & & $\begin{array}{lr}\text { kaki } & \text { yang } \\
\text { ditapung } & \text { tawar } \\
\text { dengan maksud } \\
\text { agar si ibu dan } \\
\text { jabang bayi } \\
\text { terhindar dari } \\
\text { gangguan jin, dll } \\
\begin{array}{l}\text { serta membuang } \\
\text { sial. }\end{array} \\
\end{array}$ & & & & $\begin{array}{l}\text { SAW, shalawatan, } \\
\text { dan juga ceramah } \\
\text { agama yang } \\
\text { dilaksanakan dari } \\
\text { rumah ke rumah } \\
\text { atau dikhususkan } \\
\text { pada satu tempat, } \\
\text { misal di Mushalla } \\
\text { atau Masjid, dll } \\
\end{array}$ & \\
\hline 5 & Ba'salamatan & $\begin{array}{lr}\text { Menyatakan } & \text { rasa } \\
\text { syukur atas } & \text { suatu } \\
\text { keberkahan } & \text { yang } \\
\text { diterima. } & \\
\end{array}$ & $\begin{array}{l}\text { Mengundang/mengumpulkan } \\
\text { banyak orang/kerabat/dll }\end{array}$ & 16 & Mengaji & \multirow{2}{*}{$\begin{array}{l}\text { Kegiatan } \\
\text { mempelajari dan } \\
\text { membaca kitab } \\
\text { suci Al Qur'an } \\
\text { secara bersama } \\
\text { (daras) maupun } \\
\text { dengan makhraj } \\
\text { atau tata cara } \\
\text { membaca huruf } \\
\text { dan kosa kata } \\
\text { yang benar dan } \\
\text { tepat dalam } \\
\text { Bahasa Al Qur'an. }\end{array}$} & \multirow{2}{*}{$\begin{array}{l}\text { Diikuti setiap orang yang } \\
\text { menjadi peserta atau pun yang } \\
\text { berminat mengikutinya. } \\
\text { Umumnya sudah ada anggota } \\
\text { tetap. }\end{array}$} \\
\hline 6 & Ba'kawinan & $\begin{array}{l}\text { Perayaan atas } \\
\text { perkawinan } \\
\text { seorang anak } \\
\text { gadis/perempuan } \\
\text { dengan seorang } \\
\text { jejaka/lelaki } \\
\text { dalam suatu acara } \\
\text { resepsi. } \\
\text { Kegiatan }\end{array}$ & $\begin{array}{l}\text { Mengundang/mengumpulkan } \\
\text { banyak orang/kerabat/dll }\end{array}$ & & & & \\
\hline 7 & Ba'arisan & \begin{tabular}{l}
\multicolumn{2}{l}{ perkumpulan } \\
dengan kegiatan \\
tertentu atau \\
hanya sekedar \\
mengumpulkan \\
uang dan \\
$\begin{array}{l}\text { silaturrahmi } \\
\text { sambil makan } \\
\text { bersama. }\end{array}$ \\
\end{tabular} & $\begin{array}{l}\text { Umumnya hanya dihadiri oleh } \\
\text { peserta arisan yang sudah } \\
\text { disepakati sejak awal. }\end{array}$ & 17 & PKK & $\begin{array}{lr}\text { Kegiatan } & \text { ibu-ibu } \\
\text { yang diikuti } & \text { dingan arisan dan } \\
\text { dengan } & \text { dengan } \\
\text { disisi } & \text { dengan } \\
\text { berbagai macam } \\
\text { kegiatan untuk } \\
\text { peningkatan } \\
\text { kemampuan dan } \\
\text { keterampilan }\end{array}$ & $\begin{array}{l}\text { Diikuti setiap perempuan yang } \\
\text { tergabung dalam kumpulan } \\
\text { PKK rukun tetangga atau } \\
\text { desa. }\end{array}$ \\
\hline 8 & Ba'gotong royong & $\begin{array}{lr}\text { Kegiatan } & \text { gotong } \\
\text { royong rontuk } & \text { untuk } \\
\text { memikul } & \text { suatu } \\
\text { pekerjaan yang } & \text { yang } \\
\text { akan lebih mudah } & \text { mudar cepat selesai } \\
\text { dan } & \text { bila dilakukan } \\
\text { bersama-sama. }\end{array}$ & $\begin{array}{l}\text { Mengundang anggota } \\
\text { masyarakat di lingkungan atau } \\
\text { keluarga besar untuk } \\
\text { membantu penyelesaian suatu } \\
\text { pekerjaan atau hajat. }\end{array}$ & 18 & Ba'elang & \multirow{2}{*}{$\begin{array}{l}\text { Kegiatan } \\
\text { berkunjung atau } \\
\text { bersilaturrahmi } \\
\text { dari rumah ke } \\
\text { rumah dalam } \\
\text { rangka suatu } \\
\text { urusan atau } \\
\text { sekedar menjalin } \\
\text { hubungan, } \\
\text { kekerabatan, } \\
\text { pekerjaan, dll. }\end{array}$} & $\begin{array}{l}\text { Dilakukan sesuai keperluan, } \\
\text { bisa per-orangan atau } \\
\text { beberapa orang, sesuai } \\
\text { keperluan/kebutuhan. }\end{array}$ \\
\hline \multirow[t]{2}{*}{9} & \multirow[t]{2}{*}{$\begin{array}{l}\text { Ba'aruah atau } \\
\text { ba'haul atau pula } \\
\text { disebut } \\
\text { ba'tahlilan }\end{array}$} & \multirow{2}{*}{$\begin{array}{l}\text { Kegiatan } \\
\text { mengirim doa-doa } \\
\text { atas meninggalnya } \\
\text { anggota keluarga } \\
\text { serta pembacaan } \\
\text { tahlil. } \\
\end{array}$} & \multirow[t]{2}{*}{$\begin{array}{l}\text { Mengundang/mengumpulkan } \\
\text { banyak orang/kerabat/dll }\end{array}$} & & & & \\
\hline & & & & 19 & Karasmin & $\begin{array}{l}\text { Kegiatan } \\
\text { keramaian }\end{array}$ & $\begin{array}{lr}\text { Dilakukan } & \text { dengan } \\
\text { mengundang } & \text { atau }\end{array}$ \\
\hline 10 & $\begin{array}{l}\text { Ba'muludan atau } \\
\text { Ba'maulidan }\end{array}$ & $\begin{array}{l}\text { Kegiatan } \\
\text { memperingati hari } \\
\text { kelahiran Nabi } \\
\text { Muhammad } \\
\text { SAW. }\end{array}$ & $\begin{array}{l}\text { Mengundang/mengumpulkan } \\
\text { banyak orang/kerabat/dll yang } \\
\text { diisi dengan pembacaan syair- } \\
\text { syair Maulid, pembacaan } \\
\text { Kalam Ilahi dan dilanjutkan } \\
\text { ceramah agama oleh seorang } \\
\text { ustadz/ustadzah } \\
\text { kelahiran Nabi SAW. }\end{array}$ & & & $\begin{array}{l}\text { mengumpulkan } \\
\text { orang banyak, } \\
\text { kerabat, tetangga, } \\
\text { dan handai taulan } \\
\text { dalam rangka } \\
\text { suatu hajat } \\
\text { misalnya } \\
\text { perkawinan, }\end{array}$ & $\begin{array}{l}\text { mendatangkan banyak sekali } \\
\text { orang dari berbagai kalangan, } \\
\text { bahkan yang dari jauh juga, } \\
\text { dengan kegiatan makan- } \\
\text { makan dan bersenang-senang } \\
\text { yang umumnya diisi dnegan } \\
\text { pentas seni dan budaya seperti } \\
\text { madihin, lamut, bakisah, }\end{array}$ \\
\hline \multirow[t]{2}{*}{11} & \multirow[t]{2}{*}{ Ba'mikratan } & \multirow{2}{*}{ 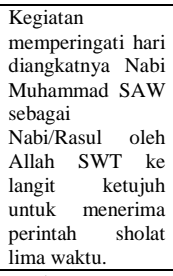 } & \multirow{2}{*}{$\begin{array}{l}\text { Mengundang/mengumpulkan } \\
\text { banyak orang/kerabat/dll yang } \\
\text { diisi dengan pembacaan syair- } \\
\text { syair Maulid, pembacaan } \\
\text { Kalam Ilahi dan dilanjutkan } \\
\text { ceramah agama oleh seorang } \\
\text { ustadz/ustadzah sekitar } \\
\text { perintah sholat, dll. }\end{array}$} & & & $\begin{array}{l}\text { sunatan, atau } \\
\text { peringatan hari } \\
\text { besar atau tanggal } \\
\text { bersejarah. } \\
\end{array}$ & $\begin{array}{l}\text { wayang gong, pantun, syair, } \\
\text { dll. }\end{array}$ \\
\hline & & & & 20 & $\begin{array}{l}\text { Tabliq Akbar atau } \\
\text { Saprah Amal }\end{array}$ & $\begin{array}{l}\text { Kegiatan mencari } \\
\text { dana untuk suatu } \\
\text { pembangunan } \\
\text { tempat ibadah } \\
\text { atau pesantren, } \\
\text { misalnya dengan } \\
\text { melelang barang }\end{array}$ & $\begin{array}{l}\text { Dilakukan di tempat terbuka } \\
\text { dan dibuat panggung untuk } \\
\text { orator/ustadz/ustadzah atau } \\
\text { petugas penggalang dana. } \\
\text { Umumnya dilaksanakan pada } \\
\text { malam hari. }\end{array}$ \\
\hline 12 & $\begin{array}{l}\text { Ba'ayun } \\
\text { Mulud/Maulid }\end{array}$ & $\begin{array}{l}\text { Kegiatan } \\
\text { mengayun } \\
\text { bayi/anak, bahkan } \\
\text { orang dewasa di } \\
\text { sela-sela } \\
\text { rangkaian } \\
\text { peringatan Maulid } \\
\text { Nabi Muhammad } \\
\text { SAW. }\end{array}$ & 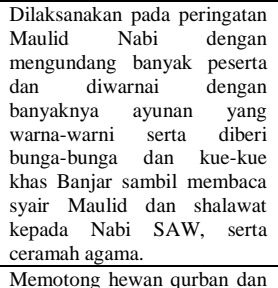 & & & $\begin{array}{l}\text { sambil } \\
\text { pertunjukan seni } \\
\text { budaya Islam, } \\
\text { shalawatan, dan } \\
\text { penyampaian } \\
\text { nilai-nilai Islam } \\
\text { melalui ceramah } \\
\text { singkat sambil } \\
\text { menghimbau } \\
\text { pengunjung untuk } \\
\text { memberikan } \\
\text { sumbangannya. }\end{array}$ & \\
\hline 13 & Ba'qurban & $\begin{array}{l}\text { Melaksanakan } \\
\text { ibadah qurban } \\
\text { pada hari raya } \\
\text { Iedul Adha. }\end{array}$ & \multirow{3}{*}{$\begin{array}{l}\text { Memotong hewan qurban dan } \\
\text { membagi-bagikan kepada } \\
\text { anggota keluarga, tetangga, } \\
\text { kerabat, handai taulan, dll } \\
\text { sebagai bentuk kepedulian } \\
\text { sosial dan perintah agama } \\
\text { Islam. } \\
\text { Diikuti setiap anggota arisan } \\
\text { yasinan/shalawatan dan juga } \\
\text { mengundang tetangga/kerabat } \\
\text { yang tidak ikut arisan untuk } \\
\text { bersama-sama berhadir } \\
\text { memeriahkan acara. }\end{array}$} & \multirow[t]{2}{*}{21} & \multirow[t]{2}{*}{$\begin{array}{l}\text { Ba'tamat } \\
\text { Qur'an }\end{array}$} & $\begin{array}{l}\text { sumbangannya. } \\
\text { Kegiatan } \\
\text { selamatan karena } \\
\text { telah menamatkan } \\
\text { atau } \\
\text { menyelesaikan } \\
\text { belajar atau }\end{array}$ & $\begin{array}{l}\text { Dilakukan di rumah atau di } \\
\text { Mushalla/Masjid dengan } \\
\text { mengundang banyak orang } \\
\text { dan disajikan nasi ketan } \\
\text { berinti kelapa muda, serta } \\
\text { telur rebus dan bendera }\end{array}$ \\
\hline \multirow[t]{2}{*}{14} & \multirow[t]{2}{*}{$\begin{array}{ll}\text { Yasinan } & \text { atau } \\
\text { Shalawatan } & \end{array}$} & \multirow{2}{*}{$\begin{array}{l}\text { Arisan membaca } \\
\text { yasin dan atau } \\
\text { shalawat kepada } \\
\text { Nabi Muhammad } \\
\text { SAW bersama- } \\
\text { sama dan ceramah } \\
\text { agama yang } \\
\text { tempatnya } \\
\text { bergiliran dari }\end{array}$} & & & & $\begin{array}{lr}\text { membaca } & \mathrm{Al} \\
\text { Qur'an dalam } & 1 \\
\text { juz. } & \\
\end{array}$ & $\begin{array}{l}\text { warna-warni yang juga kadang } \\
\text { ditempeli uang kertas } \\
\text { pecahan. }\end{array}$ \\
\hline & & & & 22 & Majlis Taklim & $\begin{array}{lr}\text { Kegiatan } & \text { belajar } \\
\text { agama } & \text { dengan } \\
\text { duduk } & \text { bersila } \\
\text { yang } & \text { disampaikan } \\
\text { oleh } & \text { seorang } \\
\text { ulama/guru/ } & \text { atau } \\
\end{array}$ & $\begin{array}{l}\text { Dilaksanakan di rumah, } \\
\text { pesantren, musholla, masjid, } \\
\text { dll secara rutin/terjadwal } \\
\text { dengan bidang kajian yang } \\
\text { runtun dari waktu ke waktu. }\end{array}$ \\
\hline
\end{tabular}




\begin{tabular}{|c|c|c|c|}
\hline No & Nama Kegiatan & $\begin{array}{l}\text { Peruntukan } \\
\end{array}$ & Makna sosialnya \\
\hline & & $\begin{array}{l}\text { ustadz/ustadzah } \\
\text { dan diikuti oleh } \\
\text { banyak orang. }\end{array}$ & \\
\hline 23 & Ba'musyawarah & \begin{tabular}{ll}
\multicolumn{2}{l}{ Kegiatan } \\
bermusyawarah \\
dalam rangka urun \\
rembug untuk \\
menemukan solusi \\
atas suatu \\
persoalan di \\
dalam kelompok/ \\
masyarakat itu.
\end{tabular} & $\begin{array}{l}\text { Dilaksanakan di lingkungan } \\
\text { rukun tetangga atau kelompok } \\
\text { lainnya yang lebih besar. Bisa } \\
\text { pula dengan mengedepankan } \\
\text { ketokohan seseorang sebagai } \\
\text { public figure decision maker. }\end{array}$ \\
\hline 24 & Takziah & $\begin{array}{l}\text { Kegiatan } \\
\text { berkunjung } \\
\text { kepada yang } \\
\text { memiliki hajat } \\
\text { atau kerabat, } \\
\text { tetangga, handai } \\
\text { taulan yang } \\
\text { keluarganya } \\
\text { meninggal dunia. } \\
\text { Baik berkunjung } \\
\text { ke rumah duka } \\
\text { saja atau sampai } \\
\text { mengantarkan } \\
\text { tempat } \\
\text { peristirahatan } \\
\text { terakhir. }\end{array}$ & $\begin{array}{l}\text { Dilaksanakan dengan tidak } \\
\text { terencana, begitu mendapat } \\
\text { pemberitahuan atau undangan } \\
\text { langsung berdatangan. }\end{array}$ \\
\hline 25 & Ba'dadamaran & 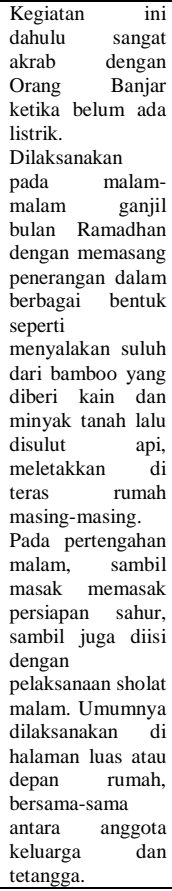 & $\begin{array}{l}\text { Biasanya dilakukan bersama- } \\
\text { sama untuk melaksanakan } \\
\text { sholat malam di pertiga } \\
\text { terakhir malam sambil sahur } \\
\text { bersama. Diantara } \\
\text { pelaksanaan sholat, sambil } \\
\text { memasak nasi dan ikan } \\
\text { melalui tungku kayu, sambil } \\
\text { berharap akan turunnya } \\
\text { lailatur qodar. }\end{array}$ \\
\hline 26 & Ba'garakan Sahur & $\begin{array}{l}\text { Kegiatan ini } \\
\text { dilaksanakan } \\
\text { sekitar pukul } 02 \\
\text { dinihari pada } \\
\text { malam-malam } \\
\text { bulan Ramadhan } \\
\text { dalam rangka } \\
\text { membangunkan } \\
\text { Umat Muslim } \\
\text { yang } \\
\text { melaksanakan } \\
\text { ibadah puasa. }\end{array}$ & $\begin{array}{l}\text { Biasanya dilakukan dalam } \\
\text { lingkup rukun tetangga atau } \\
\text { desa sambil membunyikan } \\
\text { berbagai alat apapun yang bisa } \\
\text { menghasilkan bunyi sehingga } \\
\text { orang akan terbangun dari } \\
\text { lelap tidurnya. }\end{array}$ \\
\hline
\end{tabular}

Demikian beberapa kegiatan sosial kemasyarakatan Orang Banjar yang bila dicermati memang tidak lepas dari agama dan keyakinan Islam yang dianutnya. Hal ini menunjukkan bahwa Orang Banjar itu agamis. Selain itu karaktersitik Orang Banjar adalah terbuka terhadap orang/suku/bangsa lain, mudah beradaptasi, penolong sehingga tidak mengalami kesulitan dalam bersosialisasi dengan siapapun. Pada setiap kegiatan tersebut sangat kental dengan interaksi sosial satu dengan lainnya. Sehingga sering menjadi ajang pertemuan melalui kontak langsung, interaksi dan interelasi sebagai makhluk sosial terjadi, saling mengenal atau menyambung kembali komunikasi yang pernah terputus, dll. Melalui kegiatankegiatan tersebut terjadi sosialisasi Orang Banjar dengan lingkungan, kerabat dekat dan jauh, orang baru, dan sebagainya yang makin membangun tumbuh suburnya kehidupan sosial masyarakat yang harmonis dan indah dengan lingkungannya.

\section{Tata Kelola Kearifan Lokal Orang Banjar}

Orang Banjar adalah salah satu Suku di Kalimantan adalah bagian dari Nusantara yang sangat beragam budayanya yang masing-masing suku memiliki keunikan dan kekhasan masingmasing. Sama, tetapi belum tentu persis. Karena setiap tempat dan setiap kelompok masyarakat akan melahirkan kearifan masyarakatnya sendiri. Sama bersuku Banjar dan mendapat sebutan sebagai Orang Banjar, namun kenyataannya bisa saja berbeda. Bisa berbeda logat bahasa, cara pengucapannya, penggunaannya, kebiasaannya, berbeda pernak-pernik yang digunakan dalam setiap upacara adat atau ibadah, maupun berbeda cita rasa kuliner, corak dan warna pakaian, handcraft pada bangunan rumah Banjar, dsb.

Misalnya perbedaan antara Orang Banjar yang berasal dari pesisir sungai maupun laut, penyebutan kata yang mengandung konsonan "O" pada Orang Banjar Hulu disebut dengan "U" atau "O" pecah. Ini kekhasan Orang Banjar Hulu yang sulit dihilangkan dan dibuang. Kemudian dalam citarasa lidah. Pada Orang Banjar Hulu, khususnya yang berdiam di wilayah Kecamatan Daha Utara atau dahulu disebut Nagara, makan berat (nasi) bisa dengan lauk Kolak sebagai kuah ditambah Ikan Papuyu Wadi, sudah sangat lezat sekali di lidah mereka. Namun tidak sama sekali pada lidah Orang Banjar Kuala. Sama sekali tidak bisa masuk makanan tersebut ke tenggorokannya. Atau dalam handcraft pada pakaian maupun bangunan rumah adat Banjar.

Kemudian dalam budaya religi, Orang Banjar adalah penganut agama Islam yang taat dan fanatik, maka pada peringatan hari-hari besar keagamaan sering dikaitkan dengan pemaknaan yang lainnya, lalu melahirkan budaya kearifan lokal yang tidak ada di lain tempat. Misalnya pada masyarakat di Kabupaten Tapin, ibukota Rantau. Pada setiap bulan kelahiran Nabi Muhammad SAW sebagaimana di daerah lainnya juga memperingatinya di seluruh Kalimantan Selatan, yaitu mengadakan peringatan Maulid atas kelahiran Nabi Muhammad SAW dengan berbagai cara. Tetapi pada masyarakat Tapin diikuti dengan Ba'ayun Mulud. Kegiatan dipusatkan setiap tahun di Masjid Al Mukarromah, Banua Halat, Rantau (biasa disebut Masjid Banua Halat). Uniknya Ba'ayun Mulud tidak saja ditujukan untuk bayi dan anak-anak, tetapi banyak orang dewasa bahkan 
orang tua yang mengikutinya sebagai salah satu bentuk pembayaran nazar atau lainnya.

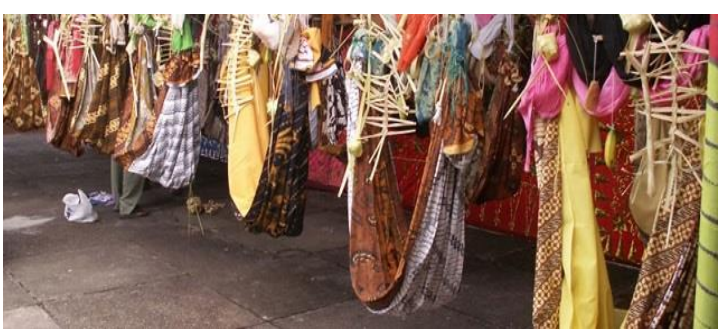

Menurut Wajidi (2014: 351), Ba'ayun Maulid adalah sebuah tradisi yang diwarisi dari masa lalu, sejak ratusan tahun. Pelaksanaan acara Ba'ayun Maulid adalah setelah acara pokok memperingati hari kelahiran (Maulid) Nabi Muhammad SAW sebagaimana di tempat/daerah lainnya, yaitu pembacaan syair-syair Maulid: Syarafal Anam, alBarzanji, al-Dibai, al-Habsyi (Maimanah dan Norhidayat, 2012: 52). Dilanjutkan dengan Kalam Ilahi, dan puncaknya ceramah agama seputar kelahiran Nabi Muhammad SAW beserta ajaranajaran yang diperintahkan Allah sebagai seorang Muslim lainnya. Pada masyarakat Kabupaten Tapin sesudah acara utama, maka dilanjutkan lagi dengan acara Ba'ayun Maulid.

Manusia tidak bisa lepas dari budayanya, demikian pula ketika terjadi migrasi atau perpindahan pemukiman, maka juga turut membawa budayanya. Sehingga Ba'ayun Maulid dalam beberapa tahun belakangan ini bukan saja dilakukan di Banua Halat, Tapin saja, tetapi seiring dengan kesadaran baru akan adanya tali ikatan dengan tradisi leluhur, maka Budaya Ba'ayun Maulid sudah menyebar ke seluruh Kalimantan Selatan. Bahkan di Banjarmasin sejak dipimpin Walikota H. Muhidin (berasal dari Rantau) melestarikan acara Ba'ayun Maulid ini juga di Kota Banjarmasin sebagai pelengkap rangkaian acara peringatan Maulid Nabi. Awalnya dipusatkan di Masjid Sultan Suriansyah. Tahun-tahun berikutnya sudah menyebar dan dilaksanakan juga di setiap Kecamatan di kota Banjarmasin pada masjid-masjid yang ada di wilayah masing-masing. Pada kota Banjarmasin pelaksanaan Ba'ayun Mulud/Maulid dilaksanakan di masjid tua seperti Masjid Jami dan Masjid Sultan Suriansyah hingga sekarang yang diikuti orang dari berbagai daerah lain, bahkan ada yang datang dari Kalimantan Tengah seperti Kapuas, Palangka Raya, Sampit, Pangkalan Bun, dll. Juga ada yang datang dari Pulau Jawa dan lainnya.

Dengan demikian acara Ba'ayun Maulid sudah lumrah pada masyarakat/orang Banjar di Kalimantan Selatan yang memiliki anak bayi sampai usia menjelang sekolah Taman KanakKanak. Kebiasaan mengayun anak/bayi ini dimaksudkan agar anak bisa tidur nyenyak dan terhindar dari gangguan nyamuk. Dengan diayun, maka nyamuk tidak akan hinggap menggigit kulit anak. Selain itu juga dengan diayun, anak akan tidur lebih lama dan lelap, karena ada angin sehingga tidak menimbulkan rasa gerah. Pada usia sekitar 5 tahun biasanya sudah tidak tidur diayun lagi, bahkan diusia 2/3 tahun sudah dibiasakan untuk tidur di Kasur.

Berikut foto-foto kegiatan Ba'ayun Maulid dari kalangan bayi dan anak-anak. Apabila bayinya rewel, biasanya ibunya mengasuh lalu duduk di ayunan bersama bayi/anaknya tersebut. Dengan diayun-ayun sambil mengikuti/mengiringi pembacaan shalawat yang dikumandangkan bersama-sama hingga mendengarkan ceramah agama yang disampaikan ulama.
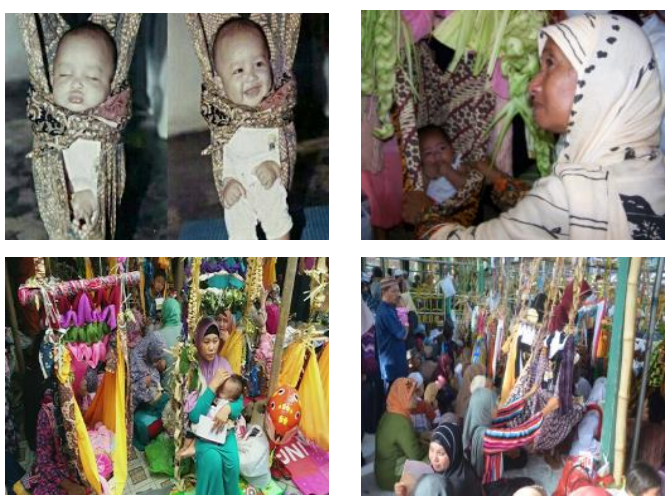

Namun seiring dengan berkembangnya budaya ini, maka Ba'ayun Maulid tidak lagi hanya untuk anak-anak, tetapi juga diikuti oleh orang tua, bahkan nenek atau kakek seusia 50 sampai 70 tahunan. Ba'ayun Maulid diikuti dengan berbagai macam tujuan dan motivasi. Diantaranya karena nazar, melestarikan tradisi, ikut merayakan hari kelahiran Nabi, menciptakan rasa kekeluargaan, karena perasaan kuatir bila tidak melaksanakan akan sakit, atau karena sudah dilakukan secara turun temurun (Maimanah dan Norhidayat, (2012: 65). Nazar misalnya dilakukan oleh perempuan yang sudah lama menikah tetapi belum dikaruniai keturunan, maka dengan Ba'ayun Maulid berharap bisa mendapatkan keturunan yang sholeh dan sholehah.

Ayunan yang digunakan dalam Ba'ayun Maulid tergolong unik, yakni menggunakan kain kuning dan dilapis dengan kain sarung, biasanya dalam jumlah ganjil. Pada tali ayunan digantungi/dihiasi dengan janur dari pohon nipah atau janur pohon kelapa maupun janur dari pohon enau. Janur dibentuk mirip dengan tangga puteri, tangga pangeran, payung singgasana, patah kangkung, kambang sarai, gelang-gelang, uang pecahan kertas, serta hal-hal lain yang berkenaan dengan aksesoris kerajaan. Jika proses Ba'ayun Maulud selesai, ayunan yang juga dihiasi (digantungi) aneka kue dan buah, seperti pisang, kue cincin, dan uang pecahan kertas, bisa dibawa 
pulang. Berikut foto-foto kegiatan Ba'ayun Maulid dari kalangan orang dewasa/tua:
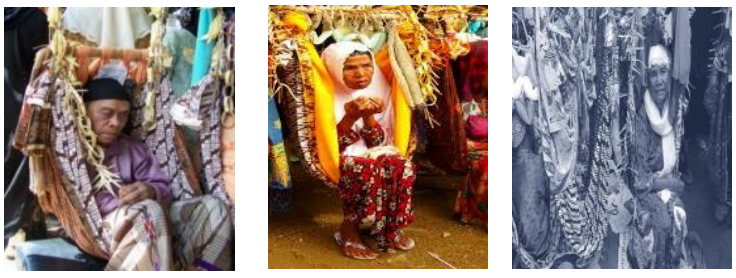

Pada kenyataannya, budaya Nusantara, khususnya Orang Banjar di Kalimantan Selatan, memiliki kekayaan tersembunyi yang luar biasa banyaknya. Sayang belum terdokumentasi dengan baik. Kalimantan Selatan yang didominasi oleh Suku Banjar, memiliki beragam tradisi dan budaya yang berbeda. Namun banyak yang belum ditulis dan didokumentasikan agar dapat diwariskan turun temurun melalui buku yang tercetak dengan baik dan apik. Apalagi dengan makin majunya peradaban dunia yang juga berpengaruh pada masyarakat, tentu akan bisa mengikis dan memudarkan tradisi yang sudah berkembang sejak nenek datuk dahulu. Apabila tidak dilestarikan dengan cara ditulis dan didokumentasikan dalam buku tercetak, maka tentu akan bisa menghilangkan sejarah, bahkan memutus tradisi yang sudah terbangun selama ini. Walaupun tidak berdampak langsung tetapi pasti secara perlahan akan bisa melunturkan dan memudarkan. Paling awal adalah hilangnya atau tidak dipahami lagi filosofi atau makna dan nilai-nilai yang terkandung pada tradisi atau budaya tersebut.

Selain budaya juga adalah cerita-cerita rakyat yang begitu penuh makna dan filosofi yang indah, akan bisa pudar dan berganti dengan cerita yang baru di era millennial ini. Karena generasi muda tidak mengenal dan tidak tahu cerita-cerita yang pernah berkembang dan turut membentuk karakter nenek kakek, ayah ibu mereka dahulu adalah cerita yang penuh dengan makna dan filosofi yang dalam. Dimana dalam cerita rakyat biasanya terkandung unsur-unsur pendidikan, pengajaran nilai-nilai luhur, norma, serta pembentukan karakter. Seperti cerita Putri Junjung Buih, Futmaraga, Lambung Mangkurat dan Dayang Diparaja, Pangeran Antasari, dll.

Berikut ini hasil yang didapat dari karya monumental tentang kearifan lokal Orang Banjar dalam terbitan dan publikasi yang sudah ditulis oleh budayawan dan cerdik cendekia Kalimantan Selatan. Diantaranya H. Syamsiar Seman yang telah berhasil menulis lebih dari 50 buku sebelum beliau wafat tahun 2013. Diantara kearifan lokal Orang Banjar yang sudah terdokumentasikan dengan baik dan berhasil diterbitkan adalah:

1. Arsitektur Tradisional Banjar, Kalimantan Selatan (2001)
2. Kesenian Tradisional Banjar, Lamut, Madihin, dan Pantun (2002)

3. Pangeran Antasari dan Meletusnya Perang Banjar (2003)

4. Lahirnya ALRI Divisi IV Pertahanan Kalimantan (2004)

5. Sasirangan: Kain Khas Banjar (2008)

6. Hassan Basry: Pahlawan Nasional (2009)

7. Paribahasa Urang Banjar (2010)

8. Perkawinan Adat Banjar, Kalimantan Selatan (2010)

9. Putri Junjung Buih: Cerita Rakyat Kalimantan Selatan (2010)

10. Intingan Lawan Dayuhan Badua Badingsanak (2001)

11. Permainan Tradisional Orang Banjar (2002)

12. Pasar Terapung (2004)

13. Burung Punai Jadi Putri Bulan (1999)

14. Kisah-Kisah Sarawin (2005)

15. Mendulang Intan (2004)

16. Proklamasi 17 Mei 1949 (2004)

17. Lambung Mangkurat lawan Dayang Diparaja (2000)

18. Pipit Dandung (1986)

19. Kisah Diang Ingsun dab Raden Penganten (2000)

20. Andi-Andi Urang Banjar Bahari (1997, dll.

Berikut beberapa contoh:
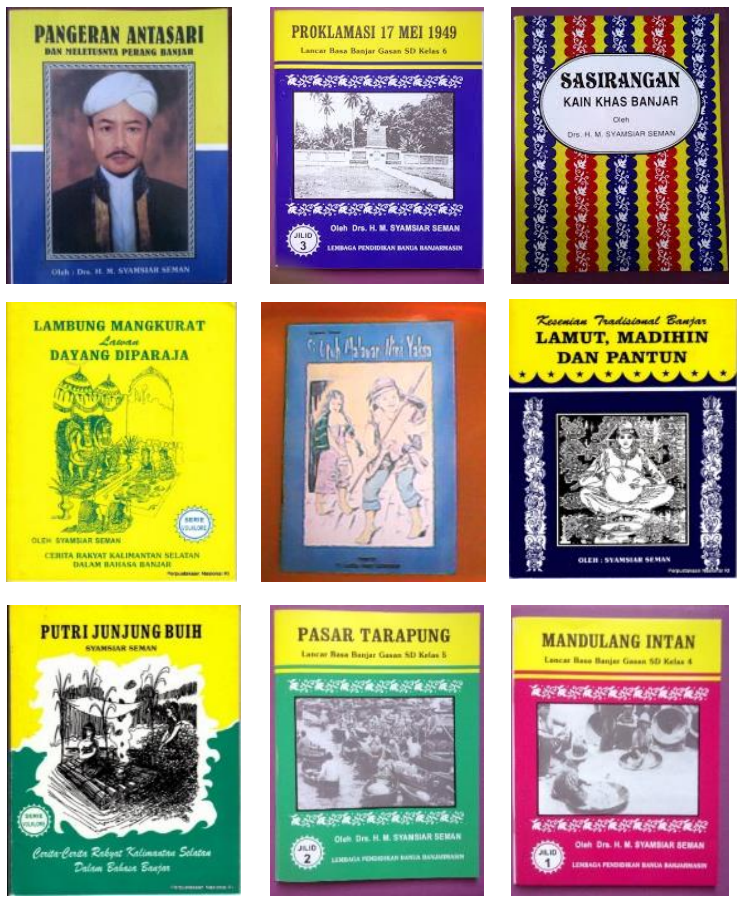

Selain karya H. Syamsiar Seman yang sudah mengangkat kearifan lokal Orang Banjar dalam sebuah buku sehingga sudah terdokumentasi dan terpublikasi dengan baik di masyarakat luas, juga ada karya Arthum Artha dan Anggraini Antemas, namun tidak banyak jumlahnya dan tidak banyak dikenal buku hasil karya tulis dua orang ini. Selain itu masih banyak kekayaan budaya Orang Banjar 
khususnya dan Kalimantan Selatan umumnya yang belum terangkat dalam karya tulis dan cetak yang bisa menjadi salah satu warisan monumental untuk generasi yang akan datang. Padahal melalui warisan monumental ini akan dapat diketahui apa yang pernah dipikirkan, dilakukan, diyakini, dipercayai, dan menjadi tradisi yang pernah akrab dalam kehidupan Suku Banjar hingga menyatu dalam semua peri kehidupannya.

Dari kalangan cerdik cendekia Perguruan Tinggi di Kalimantan Selatan, diantaranya yang sudah dibukukan terkait kearifan lokal subsuku Banjar adalah Orang Alabiu/Halabiu dengan budaya dagangnya. Sudah diteliti, ditulis dan diterbitkan menjadi buku oleh Muhaimin dengan judul "Sukses Bisnis Ala Orang Alabio" (2014). Kemudian Rahasia Sukses Bisnis Orang "Halabiu" (2015). Perang Banjar Barito ditulis oleh Ahmad Barjie B (2015). Juga buku "Menguak Peranan Sultan Hidayatullah" oleh Yanuar Ikbar (2014). Di sana banyak nilai-nilai dan makna perjuangan Orang Banjar yang terungkap dalam masa peperangan melawan penjajah di Banua Banjar. Kemudian Akhmad Tajuddin Bacco berjudul: Kaminting Pidakan. Fahruraji Asmuni berjudul: Dasar Kada Mau Kalah, dll. Belum banyak dikenal dan tersebar dalam publikasi yang mudah diakses dan ditemukan masyarakat, karena peredarannya masih terbatas.

Melalui penulisan cerita rakyat, pelestarian tradisi lokal, penerbitan buku-buku yang mengandung kearifan lokal ini tentu akan mampu menjaga keberlangsungan garis lurus keberadaan suatu suku, kearifan suatu budaya, dan bahkan kejayaan suatu suku bangsa pada masanya. Sehingga generasi muda millennial masih bisa mengenali asal muasal dirinya, leluhur dan garis keturunannya, bahkan nilai-nilai filosofis yang sangat kaya dan penuh makna. Dihadapkan dengan cerita serta budaya modern yang berkembang sekarang dan dengan dukungan teknologi modern, cenderung tidak berlangsung lama (rapuh) dibandingkan hasil adat dan budaya yang sudah diwariskan turun temurun. Bahkan ada kemungkinan terjadi kolaborasi budaya yang melahirkan kearifan lokal baru yang membuat keaneka-ragamanan baru.

Perguruan tinggi melalui cerdik cendekia memiliki tugas dan tanggung jawab yang besar melalui berbagai cara dan strategi di dalam turut melestasikan keberadaan dan hasil interaksi budaya dan tradisi dari kearifan lokal Orang Banjar yang mendiami Provinsi Kalimantan Selatan. Mestinya melalui keberadaan asosiasi penerbit perguruan tinggi akan bisa berkembang maksimal upayaupaya membantu pemerintah dalam mendokumentasikan hasil pemikiran, budaya dan tradisi yang pernah hidup dan berkembang sebelumnya maupun yang sampai hari ini masih eksis, agar diangkat dan dituangkan ke dalam sebuah tulisan yang bisa lestari dan monumental sepanjang masa. Agar keberadaan Orang Banjar dengan segala nilai, norma dan budaya yang dimiliki tetap lestasi dan terdokumentasi dengan baik agar kelak generasi yang akan datang tetap mengetahui jejak keturunan dan budaya leluhurnya. Mengingat dalam proses penulisan akan terjadi proses identifikasi, asimilasi, akumulasi dan lainnya tentang nilai dan norma yang pernah hidup dan berkembang hingga kini pada masyarakat Orang Banjar yang itu adalah kearifan lokal yang perlu terus dilestarikan dan dipublikasikan dari generasi ke generasi. Bahkan pada budaya yang berbeda di lain tempat.

Museum dan perpustakaan serta lembaga budaya adalah tempat yang tepat untuk penyimpanan, perawatan, dan tugas mengenalkannya kepada generasi muda. Selain itu juga perlu meningkatkan dan menggalakkan lomba penulisan literasi kearifan lokal Orang Banjar. Serta mengadakan kegiatan-kegiatan ilmiah serta seni budaya lainnya yang dapat mendorong dan tumbuhnya atmosfir literasi dalam menjaga dan memelihara kearifan lokal Orang Banjar guna mendukung penuh peningkatan pariwisata Kalimantan Selatan.

\section{PENUTUP}

\section{Kesimpulan}

Kearifan lokal Kalimantan Selatan sangat banyak dan beragam. Salah satu kearifan lokal yang dimiliki adalah yang berasal dari hasil tradisi dan budaya Orang Banjar sebagai salah satu suku yang paling besar mendiami Pulau Kalimantan ini. Orang Banjar memiliki kekayaan tradisi dan budaya yang turun temurun bahkan masih ada sampai sekarang, namun belum tertata, dikelola dan terdokumentasi dengan baik melalui pengadministrasian dan kegiatan manajemen lewat pengumpulan, identifikasi, penulisan, penyimpanan dan publikasi yang baik dan apik hingga diterbitkan menjadi sebuah buku. Belum banyak penulis dan budayawan maupun cerdik cendekia yang melakukan peran pengadministrasikan dan manajemen kearifan lokal Orang Banjar ini. Padahal tata nilai dan norma serta hasil adat budaya Orang Banjar yang kaya ini memerlukan tata kelola yang baik agar naskah, arsip, maupun manuskrip yang masih bersebaran maupun belum ditulis, segera ditulis dan diangkat menjadi sebuah buku yang kemudian dipublikasikan secara luas sebagai warisan monumental akan eksistensi Orang Banjar.

\section{Saran}

a. Perguruan tinggi melalui asosiasi penerbit bisa memprakarsai dan menjadi penggerak bagi gerakan literasi yang dimulai dari lingkungan ilmiah, melalui tridharma perguruan tinggi; 
b. Mendorong pihak-pihak lainnya untuk terlibat dan ikut berperan aktif melalui dana CSR untuk memberikan kontribusi pada upaya menghidupkan penulisan dan pendokumentasian karya kearifan lokal masing-masing daerah menjadi buku yang bisa diterbitkan dan diakses oleh siapa saja secara luas;

c. Mendorong Pemerintah mengeluarkan regulasi terkait penghargaan (honor dan royalti) bagi penulis, termasuk penulis yang mengangkat kearifan lokal Orang Banjar;

d. Memperbanyak kegiatan lomba penulisan pada di berbagai kesempatan, bahkan mendorong penulisan kolaborasi.

e. Mendorong tata kelola (manajemen) hasil karya tulis monumental yang ada di masyarakat melalui pendataan dan penghargaan yang baik oleh berbagai pihak.

f. Pemerintah Daerah makin intensif dalam mendorong dan memfasilitasi sosialisasi kearifan lokal Orang Banjar dalam berbagai even seni, budaya, sendratari dan pertunjukan.

\section{DAFTAR PUSTAKA}

https://id.wikipedia.org/wiki/Kearifan_lokal http://www.indonesia-heritage.net/2013/02/baayuntradisi-masyarakat-banjar/

http://wwwkaryaraji.blogspot.com/2009/01/ceritabahasa-banjar_6482.html

https://kamintingpidakan.wordpress.com/2010/05/2

5/kaminting-pidakan-sebuah-buku-ceritaberbahasa-banjar/

Maimanah dan Norhidayat. 2012. Tradidi Ba-ayun Mulud di Banjarmasin. Jurnal Al-Banjari, Hal. 51-76.

Makalah kearifan lokal adat pernikahan banjar kalimantan selatan. https://ihwatinurcahyani.wordpress.com/2012/ 04/21/makalah-kearifan-lokal-adatpernikahan-banjar-kalimantan-selatan/

Nazir, Moh., 2014. Metode Penelitian. Jakarta: Ghalia Indonesia.

Sugiyono. 2014. Metode Penelitian Administrasi. Bandung: Alfabeta

Syamsiar Seman Menulis Hingga Akhir Hayat http://kabarbanjarmasin.com/posting/syamsiar -seman-menulis-hingga-akhir-hayat.html

Tokoh Indonesia. https://tokoh.id/biografi/5-wikitokoh/menjaga-budaya-banjar-lewat-buku/

Tribun Banjarmasin.com. http://banjarmasin.tribunnews.com/2017/02/2 2/kawang-yoedha-dan-joerliani-bikin-bukuritual-adat-orang-banjar-setebal-102-halaman

Wajidi. 2014. Hubungan Islam dan Budaya Dalam Tradisi Ba-ayun Maulid di Masjid Banua Halat Kabupaten Tapin, Kalimantan Selatan. Jurnal Patarjala, Vol. 6, September 2014. Hal. 349-366.

Wikipedia. https://ms.wikipedia.org/wiki/Orang_Banjar. Download, 4 September 2018 pkl. 10.33.

Zulkarnain; Agustar, Asdi; Febriamansyah, Rudi. 2008. Kearifan Lokal Dalam Pemanfaatan dan Pelestarian Sumberdaya Pesisir (Studi kasus di Desa Panglima Raja Kecamatan Concing Kabupaten Indragiri Hilir Propinsi Riau). Jurnal Agribisnis Kerakyatan. Volume 1 Nomor 1, Juli 2008, hal.69-84.

*) Dr. Dra. Titien Agustina, M.Si., Dosen pada Sekolah Tinggil Ilmu Manajemen Indonesia (STIMI) Banjarmasin sejak tahun 1992 hingga sekarang. 